А.П. ГРИЦЕНКО

\title{
КОНЦЕПЦІЯ ФОРМУВАННЯ ПРОФЕСІЙНОЇ КОМПЕТЕНТНОСТІ МАЙБУТНІХ УЧИТЕЛІВ ІСТОРІЇ У ПРОЦЕСІ ФАХОВОЇ ПІДГОТОВКИ
}

\author{
(C) Гриценко А.П., 2019 \\ https://orcid.org/0000-0002-9107-1394 \\ http://doi.org/10.34142/2312-2471.2019.62.08
}

У статті аналізуються основні теоретичні положення концепції формування професійної компетентності майбутніх учителів історії у прочесі фахової підготовки й виокремлюються теоретичний, методичний, практичний та методологічний концеепти. Звернено увагу, щзо завдяки інтеграції ряду педагогічних підходів методологї системи (особистісно-оріснтованого, компетентнісного, гуманістичного, системного, діяльнісно-розвивального, середовищного, аксіологічного, акмеологічного, суб'єкт-суб'єктного) відбувається інтенсифікація результатів названої системи. Крім того, упровадження інтеграџійного підходу допомагає загальному об'єднанню означених принципів формування професійної компетентності майбутніх учителів історії у процесі фахової підготовки завдяки поєднанню складових освітнього прочесу (зміст, форми, методи, засоби) з інноваційністю та інтегрованістю навчання. Автор вважає, щцо професійна компетентність майбутніх учителів історіі $\epsilon$ конструктом n’яти взаємообумовлених та взаємозалежних компонентів: інформаційно-когнітивного, операційнодіяльнісного, креативно-проектного, оцінно-рефлексивного та мотиваційноціннісного. Розглядаючи професійну компетентність майбутніх учителів історії динамічною властивістю особистості, автором визначено, щзо процес ї̈ розвитку включає чотири рівні: початковий; середній; достатній; високий. У поданій статті звернено увагу, щуо дієвість концепції формування професійної компетентності майбутніх учителів історії у проиессі фахової підготовки досягається рядом педагогічних умов, основними з яких є: упровадження інноваційних технологій навчання до процесу фахової підготовки майбутніх учителів історї; створення інформаційно-освітнього середовища фахової підготовки майбутніх учителів історії у закладах вищої освіти; переорієнтація освітнього процесу на оволодіння майбутніми учителями історії методологісю науково-технічної творчості; проектування змісту освіти на основі ідей компетентнісного підходу; ияілеспрямований розвиток особистісно-професійних якостей майбутніх учителів історії.

Ключові слова: компетентнісний підхід, історія, професійна компетентність, майбутні вчителі, фахова підготовка, концепція. 


\section{Hrytsenko A. The Concept of Professional Competence Development of Future History Teachers in the Process of Professional Training}

The author of this article analyzes the main theoretical requirements in the concept of professional competence development of future history teachers in the process of professional training; and identifies theoretical, methodological, practical and methodological concepts. It is noted that due to the integration of a number of pedagogical approaches to the methodology of the system (personality-oriented, competence, humanistic, systemic, activity-developmental, environmental, axiological, acmeological, subject-subject) the results of this system are intensified. In addition, the introduction of an integrated approach helps to combine these principles of professional competence of future history teachers in the process of professional training by combining components of the educational process (content, forms, methods, tools) with innovation and integration of learning. The author believes that the professional competence of future history teachers is a construct of five interdependent and interdependent components: information-cognitive, operational-activity, creative-project, evaluation-reflexive and motivational-value. Considering the professional competence of future history teachers as a dynamic property of the individual, the author determined that the process of its development includes four levels: initial; average; sufficient; high. The article draws attention to the fact that the effectiveness of the concept of professional competence of future history teachers in the process of professional training is achieved by a number of pedagogical conditions, the main of which are: introduction of innovative teaching technologies to the process of professional training of future history teachers; creation of information and educational environment for professional training of future history teachers in higher education institutions; reorientation of the educational process to the mastering by future history teachers of the methodology of scientific and technical creativity; designing the content of education based on the ideas of the competency approach; purposeful development of personal and professional qualities of future history teachers.

Key words: competence approach, history, professional competence, future teachers, professional training, concept.

Постановка проблеми. Фахова підготовка підготовки майбутніх учителів історії в умовах розвитку освітньої сфери, іiі модернізації дедалі все більше залежить від формування професійно значущих якостей у поєднанні 3 оволодінням ними науковими фаховими знаннями, уміннями, навичками та здатностями, необхідними для творчого виконання майбутніх професійних обов'язків. У той же час, освітній процес закладів вищої педагогічної освіти все ще зорієнтований більше на традиційну освіту, ніж на логіку компетентнісної освіти, що передбачає, перш за все, дії з розв'язання самостійно обраної педагогічної проблеми, а потім вмотивоване застосування знань і вмінь, які дозволяють вирішити цю проблему. 
Виходячи із ситуації, модернізація фахової підготовки майбутніх учителів історії на засадах компетентнісної концепції є однією 3 найбільш важливих проблем сучасної вищої історичної освіти. Концепція формування професійної компетентності майбутніх учителів історії у процесі фахової підготовки спрямована на обгрунтування цілей, завдань, принципів, форм, методів, педагогічних умов та методичної системи професійної підготовки означеного фахівця.

Аналіз останніх досліджень і публікацій. Концептуальні основи реалізації компетентнісно-орієнтованого підходу до навчання досліджували вчені К. Баханов, О. Биковська, Н. Бібік， В. Безпалька І. Бех， Ю. Бойчук, С. Бондар, М. Головань, Р. Гуревич, Й. Гушулей, Н. Дем'яненко, О. Джежула, Е. Зеєр, І. Зимня, І. Зязюн, Н. Кузьміна, В. Луговий, А. Маркова, Н. Ничкало, О. Овчарук, О. Пометун, I. Родигіна О. Савченко, А. Субетто, Дж. Равен, А. Хуторськой, В. Ягупов та ін Питання фахової підготовки майбутніх учителів активно вивчалось вітчизняними та іноземними вченими О. Абдулліною, Є. Барбіною, I. Зязюном, Ж. Карташовою, Л. Кондрашовою, Н. Кузьміною, А. Ліненко, О. Пєхотою, Л. Поліщук, А. Старєвою, Л. Хомич, С. Шехавцовою та iн.

Виділення невирішених раніше частин загальної проблеми. $\mathrm{He}$ дивлячись на цілий ряд грунтовних досліджень у галузі компетентнісноорієнтованої фахової підготовки майбутніх учителів у закладах вищої освіти (далі - ЗВО), ще не створено системних досліджень проблеми формування професійної компетентності майбутніх учителів історії. Такий стан речей не лише не сприяє реформуванню освітнього процесу у закладах вищої педагогічної освіти, а й гальмує оновлення змісту професійної освіти, методів, форм, засобів навчання, нарешті, негативно впливає на впровадження компетентнісно-орієнтованого навчання.

Мета статті - систематизація, конкретизація та теоретичне узагальнення напрацьованих наукових фактів, використання результатів нових науковотеоретичних та емпіричних досліджень, методологічних підходів до визначення концепції формування професійної компетентності майбутніх учителів історії у процесі фахової підготовки.

Виклад основного матеріалу. Ефективність фахової підготовки майбутніх учителів залежить, перш за все, від рівня технолого-педагогічних знань та вмінь, професійно важливих якостей, загальної культури викладачів закладів вищої педагогічної освіти, які здійснюють фахову підготовку майбутніх учителів історії, упроваджують інновації та дотримуються положень особистісно-орієнтованого навчання. Процес фахової підготовки конкретних майбутніх учителів історії опирається на попередні етапи їх розвитку, адже «особливості попередніх вікових етапів виявляються на наступних етапах» [8, с. 94]. Втім, ще більший вплив, на наш погляд, має дотримання принципів особистісно-орієнтованого навчання. Як відомо, він передбачає рух від учня до змісту й методики, врахування його типологічних та індивідуальних 
особливостей в усіх вимірах освітнього процесу, утвердження суб'єктсуб'єктних відносин [3, с. 627].

Дослідник В. П. Безпалько [1] пов'язує концепцію з системним описом певного предмета чи явища, що сприяє його розумінню, трактуванню, виявленню первинних ідей побудови та функціонування. При цьому, система формування професійної компетентності майбутніх учителів історії у процесі фахової компетентності має включати ряд індикаторів: упорядкованість; дегенеративність; розчленованість; надійність; елементарність; детермінованість; центрованість; завершеність; іманентність; мінімальність; стаціонарність; гомогенність [10].

Таким чином, провідними ідеями концепції є: визнання унікальності й цінності особистості майбутніх учителів історії, як суб’єктів освітнього процесу, узгоджене 3 потребами сучасного суспільства; ідеї формування професійної компетентності майбутніх учителів історії у процесі фахової підготовки із забезпеченням безперервного процесу вдосконалення, самовдосконалення і саморозвитку; здійснення модернізації освітнього процесу за принципами компетентнісно орієнтованого навчання зі спрямованням основного вектору на удосконалення всіх складових освітнього процесу як системи - цілей фахової підготовки сучасних майбутніх учителів історії, методів, форм засобів навчання, контролю компетентнісних досягнень майбутніх учителів тощо.

Виходячи із науково-методологічних засад компетентнісно орієнтованої фахової підготовки, метою конщепиії визначаємо теоретичні та методичні основи процесу формування професійної компетентності майбутніх учителів історії як педагогічної системи, що забезпечує підвищення рівня та якості їх фахової підготовки у ЗВО до конструктивно-творчого розв'язання складних сучасних соціально-професійних ситуацій.

У результаті розроблення концепції формування професійної компетентності майбутніх учителів історії у процесі фахової підготовки ми визначили та розв'язано ряд завдань: виявлення стану досліджуваної проблеми в науковій літературі та педагогічній практиці; теоретичне обгрунтування та розроблення авторської концепції формування професійної компетентності майбутніх учителів історії у процесі фахової підготовки; визначення й обгрунтування методологічних підходів та принципів формування професійної компетентності майбутніх учителів історії у процесі фахової підготовки; обгрунтування принципів, чинників, цілей та виявлення педагогічних умов ефективного формування професійної компетентності майбутніх учителів історії у процесі фахової підготовки.

До цього ж відноситься створення навчально-методичного забезпечення системи формування професійної компетентності майбутніх учителів історії у процесі фахової підготовки; розроблення педагогічної системи формування професійної компетентності майбутніх учителів історії у процесі фахової підготовки з експериментальною перевіркою іiі результативності; здійснення прогностичного обгрунтування перспектив формування професійної 
компетентності майбутніх учителів історії у процесі фахової підготовки; підготовка й упровадження методичних рекомендації формування професійної компетентності майбутніх учителів історії у процесі фахової підготовки.

Виходячи із сучасних тенденцій розвитку освіти та іiі методології, принципів компетентнісного навчання, процес фахової підготовки майбутніх учителів історії, як соціального явища, направленого на вирішення певних завдань суспільства, доцільно спрямовувати на гармонійний розвиток особистості, здатної до творчості та безперервного самовдосконалення. 3 огляду на вказані провідні ідеї та позиції щодо формування професійної компетентності майбутніх учителів історії у процесі фахової підготовки, гіпотезу дослідження, теоретичні концепти розвитку особистості для розкриття змісту концепції нами визначено ряд психолого-педагогічних положень:

У контексті формування професійної компетентності майбутніх учителів історії у процесі фахової підготовки з-поміж існуючих у педагогічній науці парадигм (знаннєвої, культурологічної, технократичної гуманістичної, людиноцентристської, синергетичної, компетентнісної, особистісно розвивальної, соціальної комунікації тощо) провідною ми вважаємо гуманістичну освітню парадигму [4, с. 378]. Адже вона спрямована, перш за все, на створення умов для розвитку, становлення та самореалізації в особистому i професійному житті майбутніх учителів історії. Саме гуманістична парадигма відіграє інтегруючу, системостворюючу роль умовах формування суспільства знань, що приходить на зміну інформаційного суспільств, коли майбутній учитель переходить «...із отримувача й транслятора знань на особистість, що активно здобуває, синтезує й актуалізує знання в соціально значущу та прийнятну діяльність» [9, с. 587].

Ми вважаємо, що реалізація гуманістичної парадигми в контексті формування професійної компетентності майбутніх учителів історії у процесі фахової підготовки реалізується на ряді взаємопов'язаних методологічних підходах. Серед інших, коротко виокремимо: теоретичний, методичний, практичний та методологічний концепти. Систему психолого-педагогічних ідей, концепцій, основних понять, дефініцій, що виявляють розуміння сутності i структури формування професійної компетентності майбутніх учителів історії у процесі фахової підготовки розкриває теоретичний концепт.

Його складовими є положення психологічних теорій взаємодії та творчої діяльності; система ряду теорій (особистості, соціальних дій, мотивації діяльності, управління враженнями, теорії соціального обміну тощо); ідеях та принципах філософії та методології наукового пізнання; теорії загальнонаукових положеннях системного підходу; педагогічних принципах: загальних (науковості, наступності, безперервності, гуманізації, зв’язку теорії з практикою, наочності, інтегрованості) та специфічних (моделювання, суб'єкт-суб'єктної взаємодії, співробітництва, самоорганізації, створення розвивального освітнього середовища.

Організація самої методичної системи формування професійної компетентності майбутніх учителів історії у процесі фахової підготовки реалізовується через методичний концепт. Його реалізація відбувається через 
застосування відповідних форм та методів формування професійної компетентності; упровадження інноваційних методик та технологій; застосування сучасного навчально-методичного забезпечення 3 виробленням методичних рекомендацій формування професійної компетентності майбутніх учителів історії.

Дві останні складові свідчать про реалізацію практичного концепту, який передбачає експериментальну перевірку педагогічної системи формування професійної компетентності майбутніх учителів історії у процесі фахової підготовки. Завдяки використанню засобів діагностування (анкети, тести, опитувальні листи тощо) відбувається оцінювання результативності означеної педагогічної системи.

Взаємозв'язок різних підходів загальнонаукової i конкретно-наукової методології системи формування професійної компетентності майбутніх учителів історії у процесі фахової підготовки дозволяє представити методологічний концепт. До його складових ми відносимо ряд підходів:

- особистісно орієнтований передбачає виявлення, врахування та розвиток індивідуальних особливостей майбутніх учителів історії на основі самовдосконалення з метою розвитку особистості.

- компетентнісний передбачає формування та вдосконалення професійних знань, умінь, зокрема, у процесі фахової підготовки із забезпеченням ефективної реалізації людини-фахівця в ключових сферах іiі життєдіяльності в інтересах як іiі самої, так і суспільства.

- 2уманістичний сприяе формуванню особистості як найвищої цінності, iї морально-етичних норм, людяності.

- $\quad$ системний означає розкриття цілісності педагогічної системи, іiі оцінки, об'єкта дослідження (фахова підготовка майбутніх учителів історії), виявленням взаємозв'язку й функціональних зв'язків між її структурними компонентами 3 визначенням основних факторів впливу на систему та можливістю управління системою для обов'язкового упровадження одержаних результатів до практики фахової підготовки майбутніх учителів iсторіiі.

- діяльнісно-розвивальний - це формування професійної компетентності через конкретні дії майбутніх учителів історії.

- середовищний реалізовується через створення відповідного середовища, де відбувається формування професійної компетентності майбутніх учителів історії, як правило, у процесі виробничої практики на робочому місці вчителя.

- аксіологічний - формування системи цінностей та ціннісних відносин.

- $\quad$ акмеологічний включає самореалізацію майбутніх учителів історії у професійній діяльності за допомогою саморефлексії, самоосвіти та саморозвитку.

- культурологічний - це врахування соціокультурного контексту, формування загальної культури та культури педагогічної взаємодії. 
- $\quad$ суб'єкт-суб'єктний та коучинговий - формування особистості майбутніх учителів як суб'єктів взаємодії з подальшим обмін досвідом у процесі співпраці) тощо.

Упровадження інтеграційного підходу допомагає загальному об'єднанню означених принципів формування професійної компетентності майбутніх учителів історії у процесі фахової підготовки завдяки поєднанню складових освітнього процесу (зміст, форми, методи, засоби) 3 інноваційністю та інтегрованістю навчання.

Так, завдяки інтегрованості означених вище підходів відбувається інтенсифікація результатів системи формування професійної компетентності майбутніх учителів історії у процесі фахової підготовки. Професійна компетентність майбутніх учителів історії, на наш погляд, є конструктом п'яти взаємообумовлених та взаємозалежних компонентів: інформаційнокогнітивного, операційно-діяльнісного, креативно-проектного, оціннорефлексивного та мотиваційно-ціннісного.

Інформаційно-когнітивний компонент включає теоретичні і технологічні знання (фундаментальні, прикладні, методологічні) майбутніх учителів історії, які реалізовуються через освітню діяльність та застосування власного інтелектуального потенціалу; операційно-діяльнісний компонент являє собою взаємопов'язаний комплекс умінь і навичок професійно-педагогічної діяльності майбутніх учителів історії. Креативно-проектний компонент майбутніх учителів історії містить навички самостійної роботи, що відпрацьовуються у процесі фахової підготовки у закладах вищої педагогічної освіті в ході пошуку та опрацювання історичних відомостей, джерел, визначення їх достовірності та правдивості, самостійного створення та реалізації проєктів тощо.

Оцінно-рефлексивний компонент включає сукупність професійноособистісних якостей та професійних рис, розвинених духовної культури та педагогічної інтуїції майбутніх учителів історії з обов'язковою здатністю до рефлексії в освітній діяльності.

Мотиваційно-иіннісний компонент передбачає сформованість ціннісних та морально-етичних орієнтацій майбутніх учителів історії, прагнення до інноваційної освітньої діяльності, стійких потреб розвитку власного творчого потенціалу тощо. Розглядаючи професійну компетентність майбутніх учителів історії динамічною властивістю особистості, нами було визначено, що процес іiі розвитку включає чотири рівні: початковий; середній; достатній; високий.

На основі сказаного та аналізу підходів дослідників О. Васюк [2], В. Кручек [5], С. Лодатка [6], П. Лузана [7] для створення системи формування професійної компетентності майбутніх учителів історії у процесі фахової підготовки нами враховані ряд суперечностей, що існують на даному етапі в педагогічній теорії й практиці освітньої діяльності закладів вищої педагогічної освіти. На підставі порівняльно-історичного, функціонально-структурного аналізу вітчизняної практики фахової підготовки майбутніх учителів, модернізації освітнього процесу, розвитку інформаційного суспільства виявлено суперечності між: 
- об’єктивною потребою суспільства у висококваліфікованих та конкурентоздатних учителях історії та недостатнім рівнем професійної компетентності майбутніх учителів історії, неспроможністю існуючого процесу їх фахової підготовки забезпечити таку потребу;

- вимогами положень Законів України «Про освіту», «Про вищу освіту», Національної рамки кваліфікацій, до базових компетентностей майбутніх учителів історії та недостатньою розробленістю теоретичних і методичних основ реалізації компетентнісного підходу в освітньому процесі закладів вищої педагогічної освіти;

- новітніми завданнями закладів вищої педагогічної освіти 3 підготовки майбутніх учителів історії, здатних до подальшого навчання протягом всього життя з високим рівнем автономності та конкурентоздатності та недостатньою готовністю на сучасному етапі науково-педагогічних працівників до реалізації ідей компетентнісного підходу;

- необхідністю у фаховій підготовці професійно компетентного учителя історії з готовністю до виконання обов'язків сучасного педагога на високому рівні та недостатнім навчально-методичним та дидактичним забезпеченням процесу фахової підготовки майбутніх учителів історії.

Найважливішими педагогічними факторами розв'язання вказаних суперечностей $\epsilon$ : розвиток мотивації майбутніх учителів історії до формування професійної компетентності; упровадження до фахової підготовки використання інноваційних методик та технологій навчання; педагогічна майстерність викладачів; створення відповідного освітнього середовища 3 допомогою IT-технологій; організація навчальних та виробничих практик студентів на робочому місці вчителів історії; формування навчальнопізнавальних умінь майбутніх учителів історії; оновлення змісту освітньої програми підготовки майбутніх учителів історії; контроль навчальних досягнень майбутніх учителів історії.

Завдяки дотриманню названого комплексу факторів досягається дієвість при забезпеченні певних педагогічних умов, основними з яких є: упровадження інноваційних технологій навчання до процесу фахової підготовки майбутніх учителів історії; створення інформаційно-освітнього середовища фахової підготовки майбутніх учителів історії у ЗВО; переорієнтація освітнього процесу на оволодіння майбутніх учителів історії методологією науково-технічної творчості; проектування змісту освіти на основі ідей компетентнісного підходу; цілеспрямований розвиток особистісно-професійних якостей майбутніх учителів історії.

До основних концептуальних напрямів системи формування професійної компетентності майбутніх учителів історії у процесі фахової підготовки ми визначаємо ряд векторів: технологізація фахової підготовки майбутніх учителів історії; створення інформаційно-освітнього середовища фахової підготовки майбутніх учителів історії через інформатизацію освітнього процесу та створення інформаційно-освітнього середовища у закладах вищої педагогічної освіти; практико-орієнтована фахова підготовка майбутніх учителів історії; 
науково-дослідна робота майбутніх учителів історії; педагогічна інтеграція (загальнонауковий міждисциплінарний та внутрішньодисциплінарний напрями); оновлення стандартів педагогічної освіти.

До найбільш дієвих методів формування професійної компетентності майбутніх учителів історії у процесі фахової підготовки ви відносимо: формування досвіду суб’єкт-суб’єктної взаємодії (бесіда, дискусія - дебати, форум, круглий стіл, дерево рішень); стимулювання до взаємодії (створення ситуацій зацікавленості, метод опори на життєвий досвід, метод створення відчуття успіху); розв'язання конкретних педагогічних i технологічних ситуацій (проектувальний метод, метод ділових ігор, метод аналізу навчальних ситуацій, метод групових консультацій); діагностики результатів взаємодії (метод взаємонавчання, взаємоконтролю та взаємооцінювання).

Для формування професійної компетентності майбутніх учителів історії у процесі фахової підготовки доцільно упроваджувати систему педагогічних принципів. Серед них ми вважаємо найголовнішими такі: інформатизації (комп'ютеризації) та модульності в ході запровадження розвиваючого i виховуючого навчання та дотримання професійної мобільності в сучасних умовах. Системність формування професійної компетентності майбутніх учителів історії матиме відповідний ефект завдяки регулярному упровадженню названих вище принципів (зокрема, безперервності навчання) в ході створення інформаційно-освітнього середовища фахової підготовки майбутніх учителів історії через інформатизацію освітнього процесу у закладах вищої освіти.

Висновки. Перелічені та охарактеризовані провідні ідеї, сутнісні характеристики, цілі, завдання, гіпотеза, методологічні підходи, принципи, суперечності, фактори, педагогічні умови та напрями є засадовими позиціями проектування означеної педагогічної системи. Нами створено концептуальну модель педагогічної системи формування професійної компетентності майбутніх учителів історії у процесі фахової підготовки. У цьому контексті розроблена концепція спрямована на модернізацію змісту освіти за вимогами новітніх освітніх стандартів, запровадження інноваційних освітніх технологій в умовах створення інформаційно-освітнього середовища закладів вищої педагогічної освіти, організації продуктивного оволодіння майбутніми учителями історії знаннями засобами компетентнісно орієнтованих технологій навчання.

Перспективи подальших розвідок у цьому напрямі. Дослідження окреслило перспективи подальших наукових пошуків 3 даної тематики, що сприяє неухильному оновленню та удосконаленню процесу фахової підготовки майбутніх учителів історії в ході переведення джерел, літератури та інформаційних ресурсів у цифровий формат, збільшення ролі дистанційної форми опанування історії, суспільно-гуманітарних дисциплін та інших фаховометодичних курсів із використанням технологій мультимедіа, необхідності постійної самоосвітньої діяльності майбутніх учителів історії.

Подальшого теоретичного осмислення та експериментального апробування потребують механізми проектування змісту компетентнісної 
освіти, розроблення методичних систем фахової підготовки всебічно розвинутих, професійно компетентних, патріотично налаштованих майбутніх учителів історії.

\section{Лimepamypa}

1. Беспалько В. П. Основы теории педагогических систем (Проблемь и методы психолого-педагогического обеспечения технических обучаюших систем). Воронеж: Изд-во Воронежского ун-та, 1977. 304 с.

2. Васюк О. В. Теорія $i$ методика формування професійної спрямованості майбутніх соціальних педагогів у вищчх аграрних закладах : автореф. на здобуття наук. ступ. док. пед. наук: 13.00.04. / Нац. агр. ун-т. Київ, 2015. $40 \mathrm{c}$.

3. Енциклопедія освіти / Акад. пед. наук України; головний ред. В. Г. Кремень. Київ: Юрінком Інтер, 2008. 1040 с.

4. Кабусь Н. Д. Методологічні засади підготовки майбутніх соціальних педагогів до сталого розвитку соціальних груп. Основи сучасної педагогіки. Херсон: ПП «Вишемірський В.С.», 2016. С. $353-428$.

5. Кручек В. А. Формування комунікативних вмінь студентів вищих аграрних навчальних закладів освіти в прочесі вивчення психолого-педагогічних дисциилін : дис. ... канд. пед.. наук : 13.00.04. / Нац. агр. ун-т. Київ, 2003. 576 с.

6. Лодатко С. О. Моделювання педагогічних систем $i$ процесів: монографія. Слов'янськ: СДПУ, 2010. 148 с.

7. Лузан П. Г. Теоретичні і методичні основи формування навчальнопізнавальної активності студентів у вищих аграрних закладах освіти: дис. ... д-ра пед. наук : 13.00.04. / Нац. агр. ун-т. Київ, 2004. 505 с.

8. Максименко С. Д. Загальна психологія: навч. посібн. Вид. 3-є, переробл. та доповн. Київ: Центр учбової літератури, 2008. 272 с.

9. Рябченко В. І. Вищза школа Украӥни в загально цчивілізаційному контексті: соціально-філософський аналіз з позицій компетентнісного підходу: монографія. Київ: Фітосоціоцентр, 2015. 674 с.

10. Уемов А. И. Системный подход и общая теория систем. М.: Мысль, 1978. 272 c.

\section{References}

1. Bespalko V. P. (1977). Osnovy teorii pedagogicheskikh sistem. Voronezh: Izd-vo Voronezhskogo un-ta.

2. Vasiuk O.V. (2015). Teoriia $i$ metodyka formuvannia profesiinoi spriamovanosti maibutnikh sotsialnykh pedahohiv u vyshchykh ahrarnykh zakladakh. (Avtoref. dok. ped. nauk). Nats. ahr. un-t, Kyiv.

3. Entsyklopediia osvity. (2008). Kyiv: Yurinkom Inter.

4. Kabus N. D. (2016). Metodolohichni zasady pidhotovky maibutnikh sotsialnykh pedahohiv do staloho rozvytku sotsialnykh hrup. Osnovy suchasnoi pedahohiky. (pp. 353-428). Kherson: PP «Vyshemirskyi V.S.». 
5. Kruchek V. A. (2003). Formuvannia komunikatyvnykh vmin studentiv vyshchykh ahrarnykh navchalnykh zakladiv osvity $\mathrm{v}$ protsesi vyvchennia psykholoho-pedahohichnykh dystsyplin. (Dys. kand. ped. nauk). Nats. ahr. un-t, Kyiv.

6. Lodatko Ye. O. (2010). Modeliuvannia pedahohichnykh system i protsesiv. Sloviansk: SDPU.

7. Luzan P. H. (2004). Teoretychni i metodychni osnovy formuvannia navchalno-piznavalnoi aktyvnosti studentiv u vyshchykh ahrarnykh zakladakh osvity. (Dys. dok. ped. nauk). Nats. ahr. un-t, Kyiv.

8. Maksymenko S. D. (2008). Zahalna psykholohiia. Kyiv: Tsentr uchbovoi literatury.

9. Riabchenko V. I. (2015). Vyshcha shkola Ukrainy $v$ zahalno tsyvilizatsiinomu konteksti: sotsialno-filosofskyi analiz z pozytsii kompetentnisnoho pidkhodu. Kyiv: Fitosotsiotsentr.

10. Uemov A. I. (1978) Sistemnyy podkhod i obshchaya teoriya sistem. Moskva: Mysl. 